\title{
Effect of interleukins on the proliferation and survival of B cell chronic lymphocytic leukaemia cells
}

T Mainou-Fowler, J A Copplestone, A G Prentice

\begin{abstract}
Aims-To investigate the effects of interleukin (IL) $1,2,4$, and 5 on the proliferation and survival of peripheral blood $B$ cells from patients with $B$ chronic lymphocytic leukaemia (B-CLL) and compare them with the effects on normal peripheral blood $B$ cells.

Methods-The proliferation and survival of pokeweed mitogen (PWM) activated $B$ cells from B-CLL $(n=12)$ and normal peripheral blood $(n=5)$ were studied in vitro in response to $I L-1, I L-2, I L-4$, and IL-5. Survival of cells in cultures with or without added interleukins was studied by microscopic examination of cells and DNA agarose gel electrophoresis.
\end{abstract}

Results-Proliferation was observed in both B-CLL and normal peripheral blood cells on culture with IL-2 alone and also in some, but not all, B-CLL and normal peripheral blood cells with IL-1 and IL-4. However, there was greater variability in B-CLL cell responses than in normal peripheral blood cells. IL-5 did not affect normal peripheral blood cell proliferation but it increased proliferation in two B-CLL cases. Synergistic effects of these cytokines were not detected. IL-4 inhibited normal peripheral blood and B-CLL cell proliferation after the addition of IL-2. Inhibition of B-CLL cell responses to IL2 was also observed with IL-5 and IL-1. Survival of B-CLL cells in cultures was enhanced with $I L-4$ not by an increase in proliferation but by reduced apoptosis. No such effect was seen in normal peripheral blood cells. IL-2 had a less noticeable antiapoptotic effect; IL-5 enhanced apoptosis in B-CLL cells.

Conclusions-B-CLL and normal peripheral blood cells proliferated equally well in response to IL-2. IL-4 had a much lower effect on B-CLL cell proliferation, but had noticeable antiapoptotic activity. IL-5 enhanced cell death by apoptosis.

(f Clin Pathol 1995;48:482-487)

Department of Haematology, Derriford Hospital, Plymouth PL6 8DH T Mainou-Fowler J A Copplestone A G Prentice

Correspondence to: Dr T Mainou-Fowler.

Accepted for publication 26 September 1994
In vivo normal $\mathbf{B}$ lymphocytes derive growth factors through interactions with $\mathrm{T}$ cells and monocytes. ${ }^{1}$ In culture, however, survival and growth of activated B cells depends on the availability of external factors such as in- terleukin (IL) $4,{ }^{2} \mathrm{IL}-2,{ }^{3} \mathrm{IL}-1,{ }^{4}$ and IL-5. ${ }^{3}$ These factors could act independently or synergistically in enhancing $\mathrm{B}$ cell proliferation. ${ }^{35}$

Chronic lymphocytic leukaemia (CLL) is a neoplastic disease characterised by sustained lymphocytosis with phenotypically mature B lymphocytes inappropriately arrested at an early stage of their programming. ${ }^{6}$ B-CLL cells differ from the majority of morphologically identical, unstimulated normal small B lymphocytes in that they express a pan $\mathrm{T}$ cell associated antigen (CD5). ${ }^{6}$ As with normal B lymphocytes, the capacity of activated B-CLL cells to proliferate in response to specific cytokines such as $\mathrm{IL}-2$ and $\mathrm{IL}-4$ has been extensively investigated. A number of investigators claim that B-CLL cells show a proliferative response to IL- $2^{7-10}$ or IL-4..$^{7112}$ Others, however, noted hyporesponsiveness to either IL-2 ${ }^{12-14}$ or IL-4. ${ }^{15-18}$ Some studies focusing on IL-2 $2^{7011}$ or IL-4 $4^{711}$ have shown heterogeneity of B-CLL cell proliferative responses to such factors. This may indicate discrete stages of maturation of such cells. Also, in vitro some B-CLL cells may require signals provided by more than one cytokine in order to undergo proliferation.

Alternatively, it is possible that some B-CLL cell populations are unable to survive in culture long enough to respond to the growth factors. Such factors are important for the proliferation and survival of many cell types and, in the absence of these, cells die by apoptosis. ${ }^{19}$ Apoptosis is an active process which is important in haemopoiesis not only in the selection of $T$ and B lymphocytes, but also in the generation of myeloid ${ }^{20}$ and erythroid ${ }^{21}$ cells. This process is also involved in carcinogenesis ${ }^{19}$ and is characterised by specific molecular events ${ }^{22}$ with identifiable morphological and biochemical changes. ${ }^{23}$

The concept that different cytokines may have a proliferative role in B-CLL is relatively old, but to some extent still controversial. While some cytokines, namely IL-2 and tumour necrosis factor- $\alpha$ (TNF- $\alpha$ ), appear to be involved, the contribution of others (for example, IL-1, IL-4 and IL-5) known to affect growth of normal B cells needs to be clarified. To date, no studies have compared proliferation of $B$ CLL cells with that of normal B lymphocytes in response to growth factors. Furthermore, examination of the role of these interleukins in cell proliferation and survival may extend our understanding of the disease with implications for treatment. 


\section{Methods}

The study population comprised 14 patients with B-CLL, the demographic details of whom are summarised in the table. These patients were not receiving treatment at the time of study and were carefully selected such that more than $50 \%$ of their mononuclear cells expressed CD5 and less than $11 \%$ expressed CD2. Monoclonality of membrane immunoglobulin was demonstrated on the basis of monotypic $\kappa$ or $\lambda$ light chain expression. Healthy volunteers $(n=5)$ were picked at random and served as a source of normal peripheral blood B cells.

\section{CELL ISOLATION, PURIFICATION AND} IMMUNOPHENOTYPING

Mononuclear cells from heparinised peripheral blood samples from patients with CLL and normal volunteers were isolated by centrifugation on a Ficoll-Hypaque (Nycomed, Sheldon, Birmingham, UK) gradient. After T cell and monocyte separation by positive selection with CD2 coated magnetic beads ${ }^{24}$ (Dynabeads, Dynal, New Ferry, Wirral, UK) and adherence to plastic $\left(37^{\circ} \mathrm{C}\right.$, one hour), respectively. Cell preparations were negative and less than $0.5 \%$ positive when stained with the CD3 (Leu2b) and CD14 monoclonal antibodies, respectively, using a standard enzyme immunoassay. For immunophenotying, a standard indirect immunofluorescence method was used. Fluorescence analysis was performed on a FACSCAN flow cytometer (Becton Dickinson, Mountain View, California, USA).

\section{B CELL PROLIFERATION ASSAY}

Cells $\left(2 \times 10^{6} / \mathrm{ml}\right)$ were cultured with or without pokeweed mitogen (PWM) $(8 \mu \mathrm{g} / \mathrm{ml}$; Sigma, Poole, Dorset, UK) on microtitre plates (Gibco, Paisley, Scotland) in a total volume of $0.2 \mathrm{ml}$ RPMI 1640 culture medium (Gibco) supplemented with L-glutamine $(0.3 \mathrm{mg} / \mathrm{ml}$; Gibco), penicillin and streptomycin $(100 \mathrm{U} / \mathrm{ml}$ and $100 \mu \mathrm{g} / \mathrm{ml}$, respectively; Glaxo, Greenford, UK), $10 \%$ heat inactivated $\left(56^{\circ} \mathrm{C}, 30\right.$ minutes) fetal calf serum (Flow, Herts, UK) and 2mercaptoethanol $\left(5 \times 10^{-6} \mathrm{M}\right.$; Sigma). Recombinant IL-1, IL-2 and IL-4 (all purchased from AMS Biotechnologies, Burford, Oxford, UK) were used at $100 \mathrm{U} / \mathrm{ml}$. Human IL-5 was kindly provided by Dr C Sanderson (NIMR,
Mill Hill, London, UK). This sample gave an ED50 of 1 in 6600 in a mouse liquid eosinophil differentiation factor (EDF) marrow assay which equated to about 1 in 400000 for a human liquid EDF assay. Interleukin-5 was used at $100 \times \mathrm{ED} 50$ for the human liquid EDF assay. The cells were cultured at $37^{\circ} \mathrm{C}$ for three days in a humidified atmosphere of $5 \% \mathrm{CO}_{2}$ in air, pulsed with $1 \mu \mathrm{Ci} /$ well ${ }^{3} \mathrm{H}$-thymidine (specific activity $5.0 \mathrm{Ci} / \mathrm{ml}$; Amersham, Bucks, UK) for a further two days before being harvested on to glass fibre disks with a Diatech multiple cell harvester. The cell associated radioactivity was measured by a standard liquid scintillation counter. Each sample was cultured five times and the results were expressed as mean counts/culture.

EFFECT OF CYTOKINES ON CELL SURVIVAL

B cells $\left(1-2 \times 10^{6} \mathrm{cell} / \mathrm{ml}\right)$ from B-CLL $(\mathrm{n}=$ 4) and normal $(n=4)$ peripheral blood were cultured in medium at $4^{\circ} \mathrm{C}$ (control) $)^{25}$ or at $37^{\circ} \mathrm{C}$ (experimental) with or without cytokines. At specific time intervals, cells $(200 \mu \mathrm{l}$ aliquots) were stained with acridine orange $(5 \mu \mathrm{g} / \mathrm{ml}$; Sigma) for five minutes before the total number of stained cells and cells with visibly condensed chromatin (apoptotic) was obtained using fluorescence microscopy. At least 400 cells were counted from different fields taken at random.

\section{DNA EXTRACTION AND AGAROSE GEL}

\section{ELECTROPHORESIS}

Cells $\left(2 \times 10^{6} \mathrm{cell} / \mathrm{ml}\right)$ were lysed for four to five hours at $37^{\circ} \mathrm{C}$ in Tris-EDTA buffer (50 mM Tris, $10 \mathrm{mM}$ EDTA; pH 8.0) containing $0.5 \%$ sodium dodecyl sulphate (SDS; Sigma) and ribonuclease $(0.5 \mathrm{mg} / \mathrm{ml}$; Sigma $)$. The mixture was treated with proteinase $\mathrm{K}$ $(0.5 \mathrm{mg} / \mathrm{ml}$; Sigma) before the DNA was extracted twice with equal volume of phenol chloroform isoamyl alcohol (25:24:1 v/v, respectively; Sigma). After the addition of $0 \cdot 1$ volume of $3 \mathrm{M}$ sodium acetate ( $\mathrm{pH} 4.5$; Sigma), the DNA was precipitated with two volumes of absolute alcohol at $-20^{\circ} \mathrm{C}$ overnight followed by centrifugation for 10 minutes at 6500 $\mathrm{rpm}$ in a microcentrifuge. The precipitated DNA was redissolved in Tris-EDTA buffer (10 mM Tris, $1 \mathrm{mM}$ sodium EDTA; pH 8.0) overnight at $4^{\circ} \mathrm{C}$. DNA samples were elec-

Immunohaematological data of the patients with $B-C L L$

\begin{tabular}{|c|c|c|c|c|c|c|c|c|c|}
\hline \multirow[b]{2}{*}{ Patient } & \multicolumn{9}{|c|}{ Immunophenotypes* } \\
\hline & $W B C\left(x 10^{9} / l\right)$ & $C D 2$ & $C D 5$ & $C D 20$ & FMC7 & $C D 10$ & $C D H L A$ & $\kappa$ & $\lambda$ \\
\hline $\begin{array}{r}1 \\
2 \\
3 \\
4 \\
5 \\
6 \\
7 \\
8 \\
9 \\
10 \\
11 \\
12 \\
13 \\
14\end{array}$ & $\begin{array}{r}11 \\
25 \\
27 \\
30 \\
23 \\
43 \\
26 \\
11 \\
39 \\
13 \\
20 \\
3 \\
27 \\
132\end{array}$ & $\begin{array}{r}5 \\
2 \\
8 \\
11 \\
2 \\
7 \\
9 \\
2 \\
1 \\
9 \\
5 \\
6 \\
12 \\
2\end{array}$ & $\begin{array}{l}94 \\
50 \\
73 \\
85 \\
89 \\
80 \\
52 \\
89 \\
70 \\
78 \\
91 \\
80 \\
66 \\
98\end{array}$ & $\begin{array}{r}58 \\
66 \\
5 \\
40 \\
28 \\
39 \\
39 \\
28 \\
44 \\
62 \\
38 \\
59 \\
56 \\
75\end{array}$ & $\begin{array}{r}5 \\
24 \\
<1 \\
1 \\
<1 \\
<1 \\
10 \\
<1 \\
\mathrm{NT} \\
3 \\
2 \\
5 \\
23 \\
1\end{array}$ & $\begin{array}{r}<1 \\
<1 \\
<1 \\
<1 \\
<1 \\
1 \\
<1 \\
<1 \\
1 \\
1 \\
<1 \\
<1 \\
<1 \\
<1 \\
3\end{array}$ & $\begin{array}{l}81 \\
55 \\
67 \\
77 \\
83 \\
40 \\
56 \\
83 \\
78 \\
65 \\
85 \\
73 \\
21 \\
87\end{array}$ & $\begin{array}{r}<1 \\
<1 \\
<1 \\
46 \\
<1 \\
2 \\
1 \\
<1 \\
3 \\
\text { NT } \\
<1 \\
70 \\
80 \\
5\end{array}$ & $\begin{array}{r}<1 \\
<1 \\
<1 \\
10 \\
<1 \\
<1 \\
<1 \\
<1 \\
34 \\
\text { NT } \\
<1 \\
10 \\
8 \\
9\end{array}$ \\
\hline
\end{tabular}

* Percentage of positive cells determined by immunofluorescence; NT =not tested; WBC = white blood cells Samples from patients 13 and 14 were used for DNA agarose gel electrophoresis. 


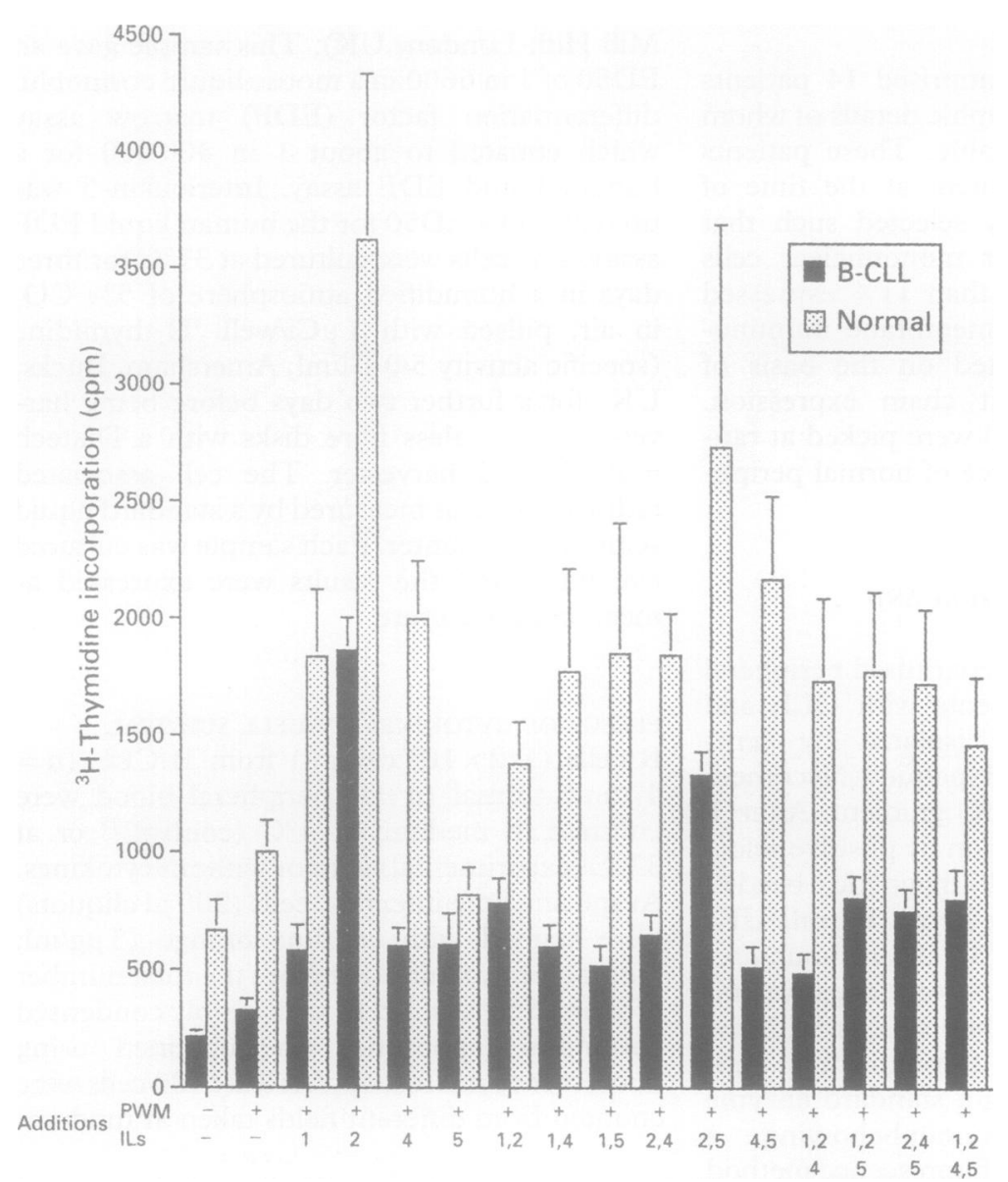

Figure 1 Proliferation of B-CLL cells (from 12 patients) and normal peripheral blood cells (from five subjects) in response to IL-1, IL-2,IL-4, and IL-5, added either singly or in combination. Cells were cultured with PWM and the appropriate concentration of interleukin(s) for five days before proliferation was measured as a function of ${ }^{3} \mathrm{H}$ thymidine incorporation. Each sample was cultured in pentaplicate and the results are expressed as mean counts/culture (mean $+S E M)$.

trophoresed on a $1.8 \%$ agarose gel in Trisborate buffer $(0.045 \mathrm{M}$ Tris, $0.5 \mathrm{M}$ boric acid, $1 \mathrm{mM}$ EDTA) containing $0.5 \mu \mathrm{g} / \mathrm{ml}$ ethidium bromide (Sigma) and photographed under ultraviolet illumination.

\section{STATISTICAL ANALYSIS}

One way analysis of variance was used to investigate whether there was a significant difference between leukaemic and normal cell response to treatment (growth factor). The homogeneity of variances was analysed using Bartlett's test. Paired $t$ test was used to analyse the effect of growth factor on either B-CLL or normal peripheral blood cell proliferation.

\section{Results}

EFFECT OF CYTOKINES ON B-CLL AND NORMAL PERIPHERAL BLOOD CELL PROLIFERATION The effect of adding cytokines to the culture medium on B-CLL and normal peripheral blood cell proliferation is presented in fig 1 . Interleukin-2 had a significant proliferative effect in all controls and in 10 of 12 B-CLL cases; the mean (range) percentage increase in proliferation was $173 \%(108-252 \%)(\mathrm{p}<0.01)$ and $458 \% \quad(197-976 \%) \quad(p<0.001)$, respectively. Interleukin-1 and IL-4 had a variable effect; with IL-1, proliferation increased in $80 \%$ (four of five) of controls by a mean of $84 \%$ $(41-125 \%)(p<0.02)$ and by $192 \%(72-405 \%)$ in four of 12 B-CLL cases $(\mathrm{p}<\cdot 001)$. Similarly, IL-4 enhanced cell proliferation by $116 \%$ (85$172 \%)$ in $80 \%$ of controls $(\mathrm{p}<0.02)$ and by $235 \%(123-400 \%)$ in four of $12 \mathrm{~B}-\mathrm{CLL}$ cases $(p<0 \cdot 001)$. Interleukin -5 had no effect on normal peripheral blood cells $(p>0 \cdot 1)$ and increased proliferation in only two of $12 \mathrm{~B}-\mathrm{CLL}$ cases by a mean of $284 \%$ (184-386\%). One way analysis of variance showed no significant differences between normal peripheral blood and B-CLL cell responses to any of the growth factors (range of $p$ values: $0 \cdot 126-0 \cdot 990$ ). However, B-CLL cell responses to all cytokines alone were more variable than those of the normal peripheral blood cells as revealed by analysis of homogeneity of the variances of the normal peripheral blood and B-CLL cell responses using Bartlett's test (range of $p$ values: $0 \cdot 021-0 \cdot 089$ ). None of the cytokines acted synergistically with regard to normal peripheral blood and B-CLL cell proliferation (fig 1). However, IL-4 significantly inhibited the response of normal peripheral blood $(p<0.02)$ and B-CLL $(p<0.001)$ cells to IL-2 (fig 1). Interleukin-1 also significantly inhibited IL-2 induced proliferation in B-CLL $(\mathrm{p}<0.02)$ and normal peripheral blood $(p<0.05)$ cells.

SURVIVAL OF B-CLL AND NORMAL PERIPHERAL BLOOD CELLS AFTER CULTURE WITH CYTOKINES In longstanding liquid culture with PWM, BCLL cells survived better in the presence of IL-4 than with any of the other cytokines (fig 2) as revealed by morphological apoptotic changes in acridine orange stained cells $(\mathrm{p}<0.05$; day 6$)$. Interleukin-2 had a less noticeable antiapoptotic effect (fig 2) which was not significant ( $p>0 \cdot 1$; day 6$)$. With IL-5, apoptosis increased during the first few days in culture (fig 2 ; IL-5, p $<0.02$ on day 1 of culture). Addition of IL-1 had no significant effect on apoptosis. On day 8 of culture, the mean

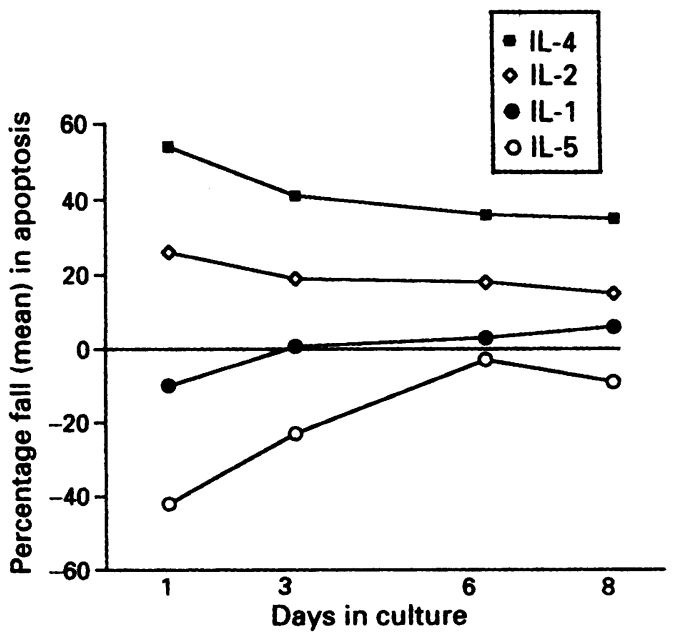

Figure 2 Percentage fall (mean) in apoptosis on addition of $I L-1, I L-2, I L-4$, and IL-5 on given days after culture at $37^{\circ} \mathrm{C}$. The difference is between percentage apoptosis in the absence and presence of cytokine ( $n=4$ for $I L-2, I L-4$ and $I L-5 ; n=3$ for $I L-1)$. 


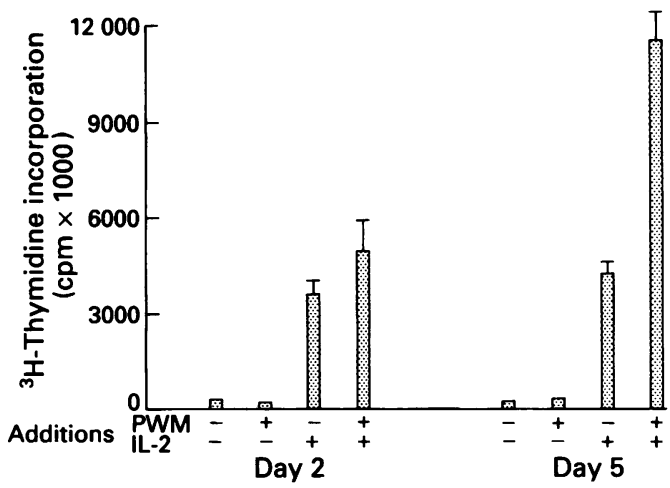

Figure 3 Proliferation of $B-C L L$ cells in the presence or absence of IL-2 or PWM. Cells were cultured in pentaplicate for two or five days before ${ }^{3} \mathrm{H}$-thymidine incorporation was measured. Results are presented as mean + SEM of three different experiments; patients 3, 9 and 10; $p<0.01$.

(range) percentage of remaining cells showing condensed chromatin and/or apoptotic bodies was $69 \%(48-82 \%) \quad(n=4)$ with no interleukins, $59 \%(39-69 \%)(n=4)$ with IL-2 alone, $48 \%(34-72 \%)(n=4)$ with IL-4, 65\% $(47-77 \%)(n=3)$ with $\mathrm{IL}-1$, and $73 \%$ (65$83 \%)(n=4)$ with IL-5. The mean (range) of percentages of apoptosis of control cultures (that is, at $4^{\circ} \mathrm{C}$ ) were as follows: with no interleukin, $3.9 \%(3 \cdot 5-4 \cdot 2 \%)(\mathrm{n}=4)$; with IL$2,4 \cdot 0 \%(2 \cdot 5-5 \cdot 1 \%)(n=4)$; with IL-4 $3.9 \%$ $(2 \cdot 9-4 \cdot 1 \%) \quad(n=4)$; with IL-1, 5.3\% (4.5$6 \cdot 2 \%)(n=3)$; and with IL-5, $4 \cdot 4 \%(3 \cdot 5-5 \cdot 2 \%)$ $(n=4)$.

Lack of mitogenic activation did not affect survival patterns of B-CLL cells in response to any of the interleukins (results not shown). The antiapoptotic activity of IL-4 was not the result of early proliferation of cells in response to this growth factor as revealed by ${ }^{3} \mathrm{H}$-thymidine incorporation experiments. However, B-CLL survival in the presence of IL-2 was most likely due to increased cell numbers as a result of cell proliferation (fig 3); proliferation with IL-2 was significantly increased in three cases studied on days 2 and 5 (fig 3; p<0.01). DNA agarose gel electrophoresis also showed that cells cultured at $4^{\circ} \mathrm{C}$ alone or with IL-4 or dexamethasone (positive control) did not undergo apoptosis (fig 4). It also confirmed that IL-4 protects against B-CLL cell death in culture as the intensity of the bands of DNA extracted from cells cultured with IL-4 was significantly weaker than that in the absence of IL-4 (fig 4). Furthermore, DNA electrophoresis revealed that IL-5 enhances apoptosis of cultured B-CLL cells; the intensity of DNA extracted from cells cultured with IL-5 was significantly stronger than that found in the absence of IL-5 (fig 5). In contrast to B-CLL cells, the percentage normal peripheral blood cells undergoing apoptosis did not decrease on culture with IL-4.

\section{Discussion}

These results confirm the previously reported observations that IL-2 enhances normal peripheral blood ${ }^{326}$ and B-CLL ${ }^{710}$ cell proliferation. As reported before, IL-4 increased proliferation of both normal peripheral blood 27 and BCLL $^{71011}$ cells. However, enhanced proliferation on culture with IL-4 was observed in fewer B-CLL cells. Although production of IL1 by B-CLL (and normal peripheral blood)

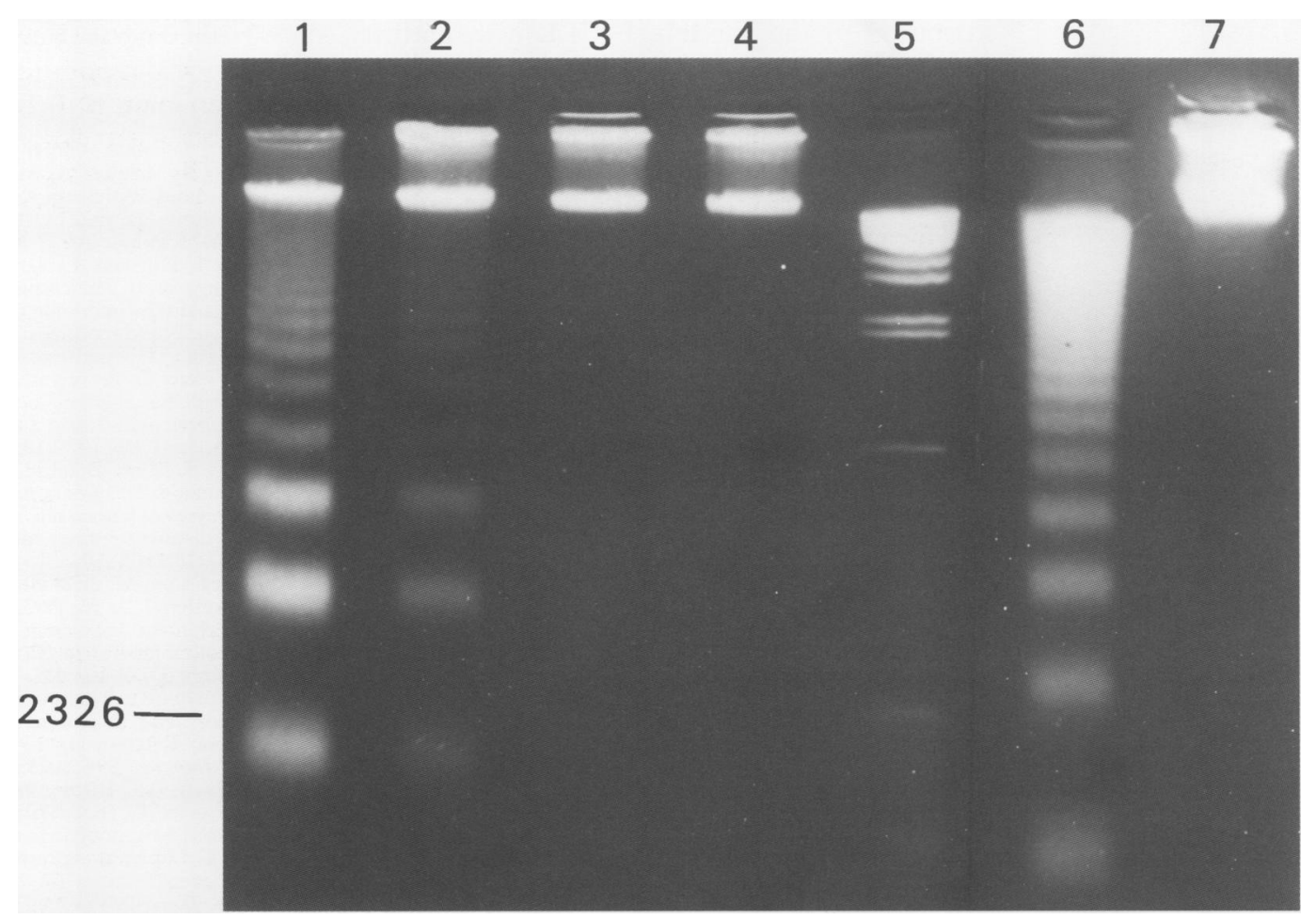

Figure 4 Agarose gel electropheresis of DNA extracted from B-CLL cells after incubation with or without IL-4 or dexamethasone. Lane 1, without IL-4 at $37^{\circ} \mathrm{C}$; lane 2, with IL-4 at $37^{\circ} \mathrm{C}$; lane 3, without IL-4 at $4^{\circ} \mathrm{C}$; lane 4, with IL-4 at $4^{\circ} \mathrm{C}$; lane 5, DNA size marker (BstE $\lambda$ digest); lane 6 , with dexamethasone at $37^{\circ} \mathrm{C}$; lane 7 , with dexamethasone at $4^{\circ} \mathrm{C}$. [DNA]/well, $2 \mu \mathrm{g}$ in lanes 1, 2, 5, 6, and 7; $1.5 \mu \mathrm{g}$ in lanes 3 and 4. Lanes 1 and 2, apoptotic DNA equivalent to 49 and $27 \%$, respectively. 


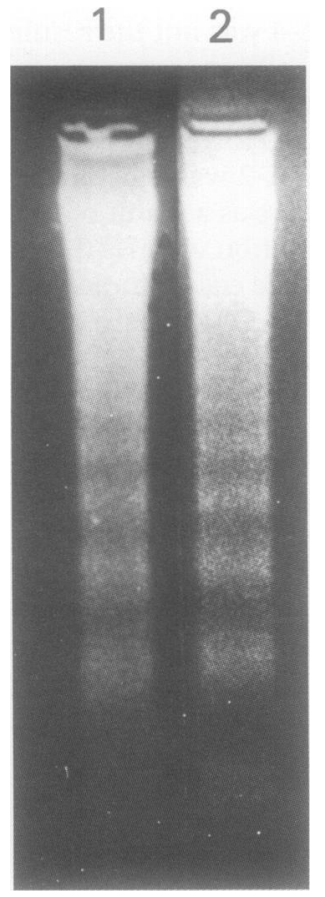

Figure 5 Agarose gel electrophoresis of $D N A$ extracted from $B-C L L$ cells after incubation for two days at $37^{\circ} \mathrm{C}$ with or without IL-5. Lane 1, no additions; lane 2, with IL5. Percentage apoptosis: lane 1, 56\%; lane 2, $77 \%$. cells is a well known phenomenon, ${ }^{28}$ there have been no reports on the effect of recombinant IL1 on B-CLL cells. This study reports significant proliferation of B-CLL (and normal peripheral blood) cells in response to IL-1. Again, this effect was observed in fewer B-CLL cells. By contrast, Uggla et $a l^{29}$ reported that B-CLL cells do not proliferate in the presence of BCLL culture supernatant fluids with IL-1-like activity.

There have been no reports on the effect of IL-5 on B-CLL B cell (that is, CD5 positive cells) proliferation although the murine cytokine has been shown to be a growth factor for $\mathrm{CD} 5$ positive lymphoma cells. ${ }^{30}$ In addition, in normal peripheral blood cells, IL-5 does not affect proliferation directly but is thought to enhance expression of $\mathrm{IL}-2$ receptors ${ }^{3}$ making the cells more responsive to IL-2. However, in this study IL-5 and IL-2 did not act synergistically in either of the cell types studied. On the contrary, IL-5 significantly inhibited the response of the B-CLL cells to IL-2. As, in this study, IL- 5 enhanced B-CLL cell death by apoptosis, inhibition of IL-2 induced proliferation by IL- 5 may have been the result of increased cell death induced by IL- 5 and not because of a direct effect on the response to IL-2. Furthermore, this study confirmed that IL-4 inhibits IL-2 induced proliferation in normal peripheral blood ${ }^{3132}$ and B-CLL ${ }^{1633}$ cells. The response of B-CLL and normal peripheral blood cells to IL-5 and IL- 1 was also inhibited. No significant differences were observed in BCLL or normal peripheral blood cell proliferation induced by any of the cytokines, either alone or in combination. The variable B-CLL cell responses to IL- $2^{71011}$ or IL- $4^{711}$ have been reported before and have been mainly attributed to the variable B-CLL cell maturity and defective expression of receptors for growth factors. ${ }^{12} 15$ B-CLL cell antigenic immaturity may also explain the hyporesponsiveness of these cells to IL-2 $2^{12-14}$ and IL-4. ${ }^{15-18}$

Survival of B-CLL cells in long term culture, as measured by the rate of apoptosis was noticeably enhanced in the presence of IL-4. Cells also seemed to survive better in the presence of IL-2. However, this enhanced cell survival in the presence of IL-2 was probably the result of proliferation. Interleukin-1 had no effect on B-CLL cell survival. By contrast, IL-5 seemed to enhance cell death by apoptosis, especially in the first few days of culture.

The apoptotic activity of IL-5 and the antiapoptotic function of IL-4 on B-CLL cells in vitro are interesting findings and require further investigation. Recently, Dancescu et $a l^{34}$ showed that IL-4 protected B-CLL cells from spontaneous and hydrocortisone induced apoptosis. Panayiotidis et $a l^{35}$ also reported enhanced B-CLL survival in vitro in the presence of IL-4 and attributed this effect to inhibition of DNA fragmentation (apoptosis) by IL-4. Dancescu et $a l^{34}$ also showed that IL-1, IL-2 and IL-5 did not have any protective effect against hydrocortisone induced apoptosis of BCLL cells. By contrast, we found that IL5 enhanced spontaneous apoptosis of B-CLL cells. How IL- 5 induces apoptosis of B-CLL cells and how IL-4 protects such cells is unknown. Generally, very little is clear about the regulation, biochemical mechanisms and identity of the genes or their products which regulate apoptosis. ${ }^{36}$

In conclusion, IL-1, IL-2, IL-4, and IL-5 induced a similar response in PWM activated B-CLL and normal peripheral blood cells. The responses of B-CLL cells to growth factors were significantly more heterogeneous than those of normal peripheral blood cells, probably the result of B-CLL surface antigenic immaturity. Survival of B-CLL cells in long term cultures was greatly enhanced by IL-4, an effect not seen in normal peripheral blood cells. Spontaneous apoptosis of B-CLL cells was not affected by IL-2 but was enhanced by IL-5. This study supports previous reports on the effect of some cytokines on B cell proliferation, but also extends our understanding of the proliferative and apoptotic responses of B-CLL cells which may enable the development of new therapeutic strategies.

This work was supported by the Plymouth and District Leukaemia Fund.

1 Arai K-I, Lee F, Miyajima A, Miyatake S, Arai N, Yokota T. Cytokines: coordinators of immune and inflammatory responses. Ann Rev Biochem 1990;59:783-836.

2 Defrance T, Vanbervliet B, Aubrey J-P, Takebe Y, Arai N, Miyajima A, et al. B cell growth-promoting activity of recombinant human interleukin-4. F Immunol 1987;139. 1135-41.

3 Hansson $M$. Growth and differentiation factors for $B$ and T cells. Leuk Res 1990;14:705-10.

4 Jelinek DF, Lipsky PE. Enhancement of human B cell proliferation and differentiation by tumour necrosis factor alpha and interleukin-1. f Immunol 1987;139:2970-6.

5 Jelinek DF, Lipsky PE. Regulation of B lymphocytic responsiveness by multiple cytokines. In: Mani JC, Dormund J, eds. Lymphocyte activation and differentiation: Fundamental and clinical aspects. Berlin: W. de Gryter, 1987:557-64.

6 Dighiero G, Travade P, Chevret S, Fenaux P, Chastang C, Binet J-L, et al. B-Cell chronic lymphocytic leukaemia: Present status and future directions. Blood 1991;78:190114.

7 Hivroz C, Grillot-Courvalin C, Brovet J-C, Seligmann M. Heterogeneity of responsiveness of chronic lymphocytic leukaemia B cells to B cell growth factor or interleukin-2. Eur $\mathcal{f}$ Immunol 1986;16:1001-4.

8 Karray S, Vazquez A, Merle-Beral H, Olive D, Debre P, Galanaud P. Synergistic effect of recombinant IL-2 and interferon-gamma on the proliferation of human monointerferon-gamma on the proliferation of human
clonal lymphocytes. $\mathcal{F}$ Immunol 1987;138:3824-8.

9 Touw I, Dorssers L, Lowenberg B. The proliferative response of $B$ cell chronic lymphocytic leukaemia to interleukin-2: functional characterisation of the interleukin2 membrane receptors. Blood 1987;69:1667-73.

10 Moberts P, Hoogerbrugge H, Van Agshoven T, Lowenberg $B$, Touw I. Proliferative response of highly purified B chronic lymphocytic leukaemia cells in serum free culture to interleukin-2 and tumour necrosis factors alpha and beta. Leuk Res 1989;13:973-80.

11 Karray S, Merle-Beral H, Vazquez A, Gerald J-P, Debre P, Galanaud P. Functional heterogeneity of B-CLL lymphocytes: Dissociated responsiveness to growth factors phocytes: Dissociated responsiveness to growth factors and distinct requirem

12 Alvarez-Mon M, de la Hera A, Gaspar ML, Orfao A, Casas $\mathrm{J}$, Jorden $\mathrm{J}$, et al. Proliferation of $\mathrm{B}$ cells from chronic lymphocytic leukaemia is selectively promoted by B cell growth factor. Acta Haematol 1989;81:91-7.

13 Benjamin D, Bazar LS, Wallace B, Jacobson R. Heterogeneity of $B$ cell growth factor receptor reactivity in healthy donors and in patients with chronic lymphocytic leukaemia: Relationship to the B cell-derived lymphokines. Cell Immunol 1986;103:394-408.

14 Freedman AS, Boyd AN, Bieber FR, Daley J, Rosen K, Horowitz JC, et al. Normal cellular counterparts of B-cel chronic lymphocytic leukaemia. Blood 1987;70:418-27.

15 Perri T. Impaired expression of cell surface receptors for B cell growth factor for chronic lymphocytic leukaemia B cells. Blood 1986;67:943-8.

16 Karray S, Defrance T, Merle-Beral H, Banchereau J, Debre $P$, Galanaud $P$. Interleukin-4 counteracts the interleukin2 induced proliferation on monoclonal B cells. $f$ Exp Med 1988;168:85-94.

17 Engel P, Ingle J, De la Calle $O$, Gallart T. Cellular activation without proliferation to $B$ cell growth factor and inwithout proliferation to B cell growth factor and in- 
ulated with phorbol ester plus $\mathrm{Ca}^{2+}$ ionophore. Clin $\operatorname{Exp}$ Immunol 1989;76:61-7.

18 Luo $H$, Rubic M, Biron G, Delespesse G, Sarfati M Antiproliferative effect of IL-4 in B chronic lymphocytic leukaemia. F Immunol 1991;10:418-25.

19 Williams GT, Smith CA, McCarthy NJ, Grimes EA. Apoptosis: final control point in cell biology. Trends Cell Bio 1992;2:263-7.

20 Williams GT, Smith CA, Spooner E, Dexter TM, Taylor DR. Haemopoietic colony stimulating factors promote cell survival by suppressing apoptosis. Nature 1990;343: 76-9.

21 Koury MJ, Bondurant MC. Erythropoietin retards DNA breakdown and prevents programmed death in erythroid progenitor cells. Science 1990;248:378-9.

22 McConkey DJ, Orrenius S, Jondal M. Cellular signalling in programmed cell death (apoptosis). Immunol Today 1990; programm

23 Arends MJ, Morris RE, Wyllie AH. Apoptosis. The role of the endonuclease. Am f Pathol 1990;136:593-608.

24 Lee T, Smeland E, Funderud S, Vartdal C, Davies K, Beiske $\mathrm{K}$, et al. Characterisation of human polymer particles for fast and specific fractionation of human mononuclea cells. Scand $\mathcal{F}$ Immunol 1986;22:207-16.

25 Ojeda F, Guarda MJ, Maldonado C, Folch U. Protein kinase-C involvement in thymocyte apoptosis induced by hydrocortisone. Cell Immunol 1990;125:535-9.

26 Mingari MC, Gerosa F, Carra G, Aecolla RS, Moretta A, Zubler $\mathrm{RH}$, et al. Human interleukin-2 promotes proZubler $\mathrm{RH}$, et al. Human in, to those of activated T cells. Nature 1984;312:641-3.

27 Gallard RE. Immunoregulation of interleukin- 4 in man. $\mathrm{Br}$ f Haematol 1991;78:293-9.
28 Pistoia V, Coliolini F, Rubatelli A, Torcia M, Roncella S, Ferrarini $M$. In vitro production of interleukin-1 by normal and malignant human B lymphocytes. $f$ Immunol 1986 ; 136:1688-92.

29 Uggla C, Aquilar-Santelises M, Rosen A, Mellstedt H, Jondal M. Spontaneous production of interleukin-1 activity in chronic lymphocytic leukaemia cells. Blood 1987; 70:1851-7.

30 Swain SL, Dutton RW. Production of B cell growth promoting activity, (DL) BCGF, from a cloned T cell line and its assay on the BCL1 B cell tumour. $\mathcal{F} \operatorname{Exp} M e d$ 1982;156:1821-34.

31 Vazquez A Mills S, Maizel A. Modulation of IL-2-induced human B cell proliferation in the presence of human 50 ha B cell growth factor and IL-4. 7 Immunol 1989;142: 94-9.

32 Paul WE. Interleukin 4: a prototypic immunoregulatory lymphokine. Blood 1991;77:1859-70.

33 Karry $S$ Daury-Varsat A Tsudo M Merle-Beral $\mathrm{H}$ Debre P, Galanaud P. IL-4 inhibits the expression of high Debre $P$, Galanaud P. IL-4 inhibits the expression of high
affinity IL-2 receptors on monoclonal human B cells. $\mathcal{F}$ Immunol 1990;145:1152-8.

34 Dancescu M, Rubio-Trujillo $M$, Biron G, Bron D, Delespesse G, Sarfati $M$. Interleukin 4 protects chronic lymphocytic leukaemic B cells from death by apoptosi and upregulates Bcl-2 expression. $\mathcal{f}$ Exp Med 1992;176: 1319-26.

35 Parayiotidis P, Ganeshbaguru K, Jabbar SAB, Hoffbrand AV. Interleukin-4 inhibits apoptotic cell death and loss of the bcl-2 protein in B-chronic lymphocytic leukaemia cells in vitro. Br $¥$ Haematol 1993;85:439-45.

36 Raff MC. Social controls on cell survival and death: an extreme view. Nature 1992;356:397-401. 